\title{
POTRZEBY BADAWCZE W ZAKRESIE BIBLIOTEK SZKOLNYCH I PEDAGOGICZNYCH
}

Głównym celem współczesnego kształcenia jest wychowanie człowieka, który nie tylko będzie dysponował określonym zasobem wiedzy i umiejętności, ale będzie także zdolny do dalszego samokształcenia, który będzie musial elastycznie kierować sobą w nowych sytuacjach, w obliczu nowych zadań kreowanych przez warunki polityczne, społeczne, ekonomiczne. W światowej dydaktyce sprawę tę uznano za pierwszoplanową. Dydaktykę, której głównym celem jest nauczanie młodzieży samodzielności uczenia się, Czesław Kupisiewicz określił mianem „dydaktyki generatywnej", będącej podstawą szerszego zjawiska współczesnej pedagogiki - edukacji permanentnej (ustawicznej) ${ }^{1}$.

Współczesne raporty oświatowe ZSRR, Stanów Zjednoczonych A.P., Francji, Japonii i innych krajów uprzemysłowionych charakteryzują się pełną zgodnością poglądów w tym zakresie, niezależnie od odmiennych zadań szczególowych, jakie wyznaczają systemom szkolnym rządy poszczególnych krajów.

Realizacja tak pojętych celów kształcenia implikuje rozliczne zmiany w metodach i formach nauczania, w wyposażeniu szkół w pomoce naukowe i dydaktyczne. Wspólczesna dydaktyka przewiduje stosowanie różnorodnych metod i form kształcenia: od nauczania grupowego do indywidualnego, od zajęć klasowo-lekcyjnych do grup laboratoryjnych i seminaryjnych. Szczególne walory kształcące i wychowawcze przypisuje się metodzie nauczania problemowego, której realizacja wymaga z kolei rozbudowy tzw. technologii kształcenia - a przede wszystkim wyposażenia szkół w nowoczesne urządzenia i środki dydaktyczne.

Nowe cele i środki kształcenia, podkreślenie konieczności przygotowania ucznia do samodzielnego zdobywania wiedzy $i$ jej przetwarzania (co jest podstawą dydaktyki generatywnej) a tym samym do uczestnictwa w kształceniu ustawicznym (a szerzej w kulturze), zmiany form organizacyjnych i metod kształcenia oraz rozwój technicznych środków dydaktycznych (kształcenie multimedialne) mają bezpośredni wpływ na organizację i metody pracy szkoły, a biblioteka szkolna jako organiczna część tej instytucji - przemianom tym także podlega.

Funkcje i działania bibliotek szkoinych należy rozpatrywać dwutorowo ${ }^{2}$.

Tor pierwszy - to wspóluczestniczenie w procesie dydaktycznym i wychowawczym szkoły. Współuczestnictwo to jest wyznaczane aktualnymi zadaniami dydaktyki oraz stanem rozwoju jej komponentów. Biblioteka szkolna służy:

- pomocą w realizacji procesu dydaktyczno-wychowawczego szkoły (zarówno w stosunku do uczniów, jak i nauczycieli),

- wyrównywaniu indywidualnych różnic w przygotowaniu uczniów, 
- kształceniu przyszłego użytkownika informacji,

- rekreacji uczniów i nauczycieli.

Jednocześnie biblioteki szkolne są częścią ogólnokrajowej sieci bibliotecznoinformacyjnej (ogniwem, z którym styka się każdy człowiek w wieku szkolnym) - a więc nie mogą one działać w oderwaniu od polityki państwa w zakresie bibliotek i informacji. Polityka państwa w tym zakresie wyznacza tej sieci bibliotecznej określone zadania; biblioteki szkolne zaś swoją działalnością partycypują w ogólnym programie rozwoju służb bibliotecznych i informacyjnych.

Współczesne narodowe programy i standardy rozwoju bibliotekarstwa szkolnego ${ }^{3}$ oraz wytyczne programu UNESCO-UNISIST $\|^{4}$ na czoło wysuwają funkcje informacyjną bibliotek szkolnych. Jako najliczniejsza grupa bibliotek wśród całej sieci bibliotecznej (ponad 19.000 placówek w Polsce), ogarniająca użytkowników w wieku szkolnym, ma ona do spełnienia zadanie przygotowania ucznia do korzystania z innych bibliotek, archiwów, ośrodków informacji, innych placówek kultury i oświaty - tworzących wspólnie krajowe zasoby informacji w obrębie tzw. infrastruktury informacyjnej kraju.

W myśl założenia programowego UNISIST biblioteka szkolna winna systematycznie kształcić młodzież w zakresie posługiwania się zasobami informacji dostępnymi w kraju. Wprawdzie obowiazki biblioteki szkolnej w zakresie upowszechniania umiejętności korzystania z informacji są obecnie wysuwane na pienwsze miejsce - nie zmienia to jednak faktu, że biblioteka szkolna to także placówka rozwijająca i utrwalająca zainteresowania czytelnicze dzieci i młodzieży, to biblioteka także o charakterze rekreacyjnym.

Teoria i praktyka bibliotekarstwa szkolnego za granicą (Stany Zjednoczone A.P., Wielka Brytania, Francja, Republika Federalna Niemiec, kraje skandynawskie) wytyczyła pewne kierunki rozwoju tym placówkom, umownie nazwane w literaturze fachowej „modelem angloamerykańskim”. . Kierunki te wyznaczają bibliotekom szkolnym funkcję ,źródłowych ośrodków informacji" (,media resource center'), odgrywających podstawową rolę dydaktyczną w procesie nauczania i uczenia się. Nie wnikając, w tym miejscu, w założenia szczegółowe tego modelu, które dotyczą środków materialno-technicznych działalności bibliotek szkolnych i są uzależnione od poziomu rozwoju gospodarczo-ekonomicznego danego kraju, należy zwrócić uwagę na wyznaczniki, które model ten określają. Są nimi:

- zmiany w formach i metodach procesu dydaktycznego, który w organizacji wewnętrznej szkoły jest realizowany w dużym stopniu w bibliotece,

- operowanie w działalności dydaktycznej i bibliotecznej najszerzej pojętym dokumentem (nośnikiem informacji).

Współczesny model biblioteki szkolnej jest determinowany przez panujące kierunki w dydaktyce. Realizacja celów dydaktyki generatywnej, przygotowującej młodzież do uczestnictwa w ksztalceniu permanentnym wymaga stałego kontaktu młodzieży z książką, czasopismem, innymi formami dokumentów, z warsztatem informacyjno-bibliograficznym. Rozwój dydaktyki w kierunku jej większej indywidualizacji wymaga z kolei odpowiedniego warsztatu pracy; biblioteka w szkole jest więc interdyscyplinarną pracownią do studiów indywidualnych. W bibliotece szkolnej uczeń winien przyswajać wiedzę, w sposób dla siebie najbardziej odpowiedni, 
mając do dyspozycji zbiór biblioteczny w postaci dokumentów ksiażkowych i nieksiążkowych. Ta wewnętrzna, na potrzeby szkoły, funkcja biblioteki szkolnej jest ściśle powiązana z koncepcją nauczania szkolnego. Biblioteka kształtuje się jako centralne laboratorium szkolne, w którym może rozwijać się bardziej intensywna praca nad pogłębieniem zainteresowań i przewidzianej programem wiedzy. Usytuowana, według założeń modelu anglo-amerykańskiego, przeważnie w centrum szkoły, łatwo dostępna, umożliwia nawet najbardziej intensywna pracę, zarówno indywidualną, jak i grupową. Biblioteka szkolna przestaje być wyłącznie miejscem okazjonalnego pobytu ucznia a zaczyna funkcjonować jako dydaktyczne centrum szkoły.

Niestety, przedstawione wyżej założenia tenretyczne dotyczące funkcjonowania bibliotek szkolnych czy to w dydaktyce, czy w ogólnokrajówej sieci biblioteczno-informacyjnej oraz kierunki rozwoju tych placówek wytyczone w programach o charakterze międzynarodowym nie zostały dotąd urzeczywistnione w Polsce.

Mimo że biblioteki szkolne w Polsce mają naturalną "nadbudowę" w postaci samoistnej sieci bibliotek pedagogicznych dla ponad 600-tysięcznej grupy nauczycieli (co jest rozwiązaniem, obok przykładu węgierskiego niespotykanym), mimo istnienia bibliotek naukowych i zakładów informacji naukowej działających w resorcie edukacji naukowej - udział bibliotek szkolnych i pedagogicznych w procesie dydaktyczno-wychowawczym szkoły ma raczej charakter bierny, a nie czynny.

Obecny stan organizacji bibliotek szkolnych wpływa na ich działalność w zakresie pracy z uczniem. Mimo obowiązującego „Programu pracy biblioteki szkolnej", dokumentu nie odbiegającego w swej wymowie od innych tego typu w świecie, biblioteka jako ośrodek (centrum) informacji, jako ośrodek dydaktyczny, jako pracownia interdyscyplinarna $w$ szkole - to $w$ warunkach polskich postulat a nie rzeczywstość. Podobnie, obsenwowany u nauczycieli spadek oddziaływania na nich bibliotek pedagogicznych, spadek aktywności czytelniczej - świadczy o niepełnym wykorzystaniu tej sieci bibliotecznej przez polskich pedagogów, z których blisko połowa jest zobligowana do uzupełnienia wiedzy na poziomie wyższym.

Systematyczne badania nad realnie spełnianą przez biblioteki szkolne i pedagogiczne funkcją $w$ dydaktyce, a szerzej w systemie oświaty są do tej pory w Polsce nie podjęte. Jest to bardzo płodny $i$ istotny obszar badawczy ze względów nie tylko poznawczych ale i społecznych. Wnioski z dotychczasowych, wyrywkowych rozpoznań tego problemu w Polsce moga być nieścisłe i nieprzekonywujące ale wskazują na to, że dydaktyka uprawiana w polskich szkołach nie wymaga konieczności przekształcania tradycyjnych książnic w kierunku szkolnych ośrodków informacyjnych (źródłowych). Jest to wdzięczne pole badawcze zarówno dla pedagogów jak i bibliotekoznawców.

Biblioteki szkolne i pedagogiczne oprócz spełniania zadań związanych z realizacją procesu dydaktycznego i wychowawczego w szkole są jednocześnie ogniwami ogólnokrajowej sieci biblioteczno-informacyjnej. Jako placówki informacji pedagogicznej, przeznaczonej głównie dla nauczycieli-praktyków, biblioteki te muszą włączyć się do krajowej sieci biblioteczno-informacyjnej.

Integracja funkcjonalna wszystkich placówek bibliotecznych i informacyjnych w naszym kraju (w tym bibliotek szkolnych i pedagogicznych) jest realną szansą 
sprostania problemom spolecznym w tym zakresie, w Polsce lat 90 . Właczenie bibliotek szkolnych i pedagogicznych, tworzących podstawową i najszerszą terytorialnie sieć placówek informacji pedagogicznej do krajowego systemu informacyjnego nie wynika wyłącznie z założeń strukturalnych i organizacyjnych krajowej sieci biblioteczno-informacyjnej czy z międzynarodowych zaleceń UNESCO. Jest to konieczność, która wynika z potrzeb zawodowych nauczycieli, z potrzeb praktyki szkolnej.

Projekt systemu biblioteczno-informacyjnego dla byłego resortu oświaty i wychowania był konkretną propozycją włączenia bibliotek szkolnych i pedagogicznych w strukturę podsystemu dziedzinowo-gałęziowego, jakim jest podsystem w zakresie informacji pedagogicznej, a więc pośrednio jest próbą umiejscowienia tych bibliotek w krajowym systemie informacji.

Z przeprowadzonej przeze mnie analizy działalności bibliotek szkolnych i pedagogicznych w Polsce, $z$ uwzględnieniem ich roli w procesie dydaktyczno-wychowawczym szkoły oraz podjętej próby ich systematycznego włączania do krajowej sieci biblioteczno-informacyjnej ${ }^{6}$ wynika szereg wniosków, których realizacja zadecyduje o tym, czy biblioteki te będą w stanie aktywnie uczestniczyć w praktyce szkolnej oraz w systemie informacji pedagogicznej. Wymieniony wyżej materiał pozwala na skupienie wniosków w kilku obszarach:

1. Konieczność prowadzenia przez zainteresowane środowiska prac badawczych w zakresie funkcjonowania bibliotek szkolnych i pedagogicznych w procesie dydaktyczno-wychowawczym szkoły oraz ich miejsca w krajowej sieci (systemie) biblioteczno-informacyjnej.

Szczególnie istotne staje się podjęcie prac badawczych nad modelem biblioteki szkolnej w Polsce w świetle prognoz demograficznych. W latach 80-tych mieliśmy do czynienia z kolejnym wyżem dzieci i młodzieży w wieku szkolnym (7-14 lat), który spowoduje w latach następnych wzrost zapotrzebowania na wykształcenie ponadpodstawowe. Według prognoz oświatowych 53-57\% absolwentów szkół podstawowych trafiać będzie do zasadniczych szkół zawodowych, zaś około $40 \%$ zdobywać będzie wyksztalcenie średnie, z przewagą zawodowego.

Prace badawcze w tym zakresie winny skupiać się wokól problematyki funkcji biblioteki w szkole podstawowej, zasadniczej zawodowej i średniej (zawodowej i ogólnokształcącej) ${ }^{7}$.

Wyniki badań mogłyby mieć wpływ na stosowanie w praktyce bibliotecznej odpowiednich form i metod pracy z młodym czytelnikiem, zwlaszcza tym, który ukończy edukację na poziomie szkoły zasadniczej lub średniej zawodowej.

Innym istotnym obszarem badawczym, mieszczącym się w problematyce modelu biblioteki, jest zagadnienie relacji między dydaktyką uprawianą w szkole a działalnością biblioteki szkolnej. Na ile dydaktyka implikuje działalność bibliotek?

Badań wymagają także problemy związane z działalnością sieci bibliotek pedagogicznych, których główni użytkownicy - nauczyciele mają konkretne potrzeby informacyjne. Winny to być badania potrzeb nauczycieli (i innych użytkowników informacji pedagogicznej) przeprowadzone z punktu widzenia procesów przekazywania i wykorzystywania informacji. 
Należy także określić miejsce bibliotek szkolnych i pedagogicznych w krajowej sieci biblioteczno-informacyjnej.

Wynik badań mógłby niewątpliwie posłużyć centralnej administracji szkolnej oraz innym organom kształtującym system oświatowy państwa w prowadzeniu jasno określonej i konsekwentnej polityki w stosunku do bibliotek i czytelnictwa uczniów i nauczycieli. Widoczny brak takiej polityki może wyjątkowo ujemnie zaważyć na przyszłości dostępu ucznia i nauczyciela do książki i informacji.

2. Już dziś wydaje się niezbędne przeprowadzenie zmian strukturalnych i funkcjonalnych w organizacji i administracji placówek biblioteczno-informacyjnych przeznaczonych dla uczniów i nauczycieli a przede wszystkim podjęcie działań na rzecz włączenia bibliotek szkolnych i pedagogicznych do systemu informacji pedagogicznej w obrębie krajowego systemu informacji naukowej, technicznej i organizacyjnej. Pozwoli to w przyszłości na wypracowanie zasad bliższej funkcjonalnej współpracy bibliotek szkolnych i pedagogicznych z bibliotekami publicznymi, fachowymi, z ośrodkami informacji, archiwami i innymi instytucjami oświaty równoległej.

3. Konieczność zmian w organizacji wewnętrznej bibliotek szkolnych i pedagogicznych jest konsekwencją wniosków poprzednich. Na czoło wysuwają się tu działania na rzecz stabilizacji kadry bibliotecznej, prowadzenie właściwego systemu jej kształcenia, dokształcania i doskonalenia zawodowego oraz konieczność rozwiązań normatywnych głównie w zakresie struktury formalnej i rzeczowej zbiorów, zasad finansowania biblioteki, jej warunków lokalowych i technicznego wyposażenia.

4. Konieczność zmian w systemie kształcenia nauczycieli i bibliotekarzy szkolnych. Ze względu na obowiązki biblioteki szkolnej w zakresie przygotowania ucznia do korzystania $z$ informacji niezbędne jest kształcenie wszystkich nauczycieli w zakresie podstaw informacji naukowej. Duże, niezaspokojone zapotrzebowanie społeczne na kwalifikowanych bibliotekarzy szkolnych winno powodować rozwijanie specjalizacji w zakresie bibliotekarstwa szkolnego i pedagogicznego w uniwersytetach, a zwłaszcza w wyższych szkołach pedagogicznych. Obecnie specjalizacja ta jest radko reprezentowana w poiskich szkołach wyższych.

\section{Przypisy}

${ }^{1} \mathrm{Cz}$. Kupisiewicz, Kerunki modernizacji ks ztalcenia. Referat wygloszony 11 I 1976 r. w Uniwersytecie Warszawskim, Warszawa 1976, maszyn. powiel. Biblioteka Uniwersytetu Warszawskiego.

${ }^{2}$ M. Drzewiecki, Współczesna biblioteka szkolna, Warszawa 1980.

${ }^{3}$ Biblioteki szkolne za granicą, Warszawa 1980. Zeszyty Przekladów nr 41.

${ }^{4}$ Szczęch W., Międzynarodowe programy, sieci i systemy informacji naukowej. Przewodnik, Warszawa 1984.

${ }^{5}$ M. Drzewiecki, Biblioteki szkolne i pedagogiczne w Polsce. Rola w procesie dydaktycznym i miejsce w krajowej sieci biblioteczno-informacyjnej, Warszawa 1990. Wydawnictwa Uniwersytetu Warszawskiego. Rozprawy nr 348.

6 Tamże.

${ }^{7}$ Koncepcja programu kształcenia ogólnego w polskich szkołach, Warszawa 1991, masz. powiel. Ministerstwo Edukacji Narodowej. 